that the unit of heredity, a gene locus, may control several reactions; and, working with maize, use of a special technique has brought an unstable gene into proximity with a stable gene locus, thus permitting a fuller analysis of the composition and action of the normal locus. Studies of the genetics of the resistance to streptomycin of Escherichia coli have indicated that what appears to be a single gene locus controls a series of reactions, and the reverse changes in locus are probably not brought about through a reversal of the original chemical reaction, but through some other change in the same gene locus. The bacterial resistance to aureomycin, chloromycetin and neomycin, the mutagenic action of chemicals on the sperm of Drosophila, the cytology of bacteria, the organisation of the chromosome, the genetic structure of natural populations among tropical Drosophila, and intracellular growth and genetics of bacteriophage have all received attention, while the analysis of the mechanism of action of individual genes has continued. In mouse leukæmia evidence has been obtained that the age of the mouse has as certain an influence on the incidence of spontaneous leukæmia after birth and on the length of life as has the age of the mother before birth. In the Division of Historical Research studies have continued on the early cultures in the Guatemala highlands, of ceramic technology and of the ceramic sequences of the lowlend Maya area in eastern Campeche.

\section{PROF. F. SEVERI'S SCIENTIFIC JUBILEE}

$T$

HE year 1949 marked two events of cardinal importance to mathematics : the centenary of the Annali di Matematica, and the seventieth birthday of Prof. Francesco Severi, director of the Istituto Nazionale di Alta Matematica, Rome, and for many years the chief editor of the journal. It thus seemed peculiarly appropriate to Prof. Severi's colleagues that a celebration should be organised to commemorate the double event; accordingly, a national cornmittee was formed, under the chairmanship of Senator G. Castelnuovo, to consider what steps might be taken to this end.

It was then decided: to offer the Annali for the year 1949-50 in homage to Prof. Severi, and to invite contributions from representative mathematicians, of all nationalities, to this number; to initiate the publication of Prof. Severi's selected papers in four volumes, arranging to complete the first volume in time for presentation at a ceremony to occur later in the year ; and to found a commemorative scholarship at the Institute. To these projects was afterwards added a fourth, namely, the expansion of the ceremony, as originally planned, into a miniature international congress, at which foreign mathematicians should be invited to participate, thereby lending an additional and general interest to the occasion.

Eventually it proved expedient to postpone the proceedings to 1950 , again a significant year, as marking the half-century of Prof. Severi's scientific activity. The date finally fixed for the ceremony was April 25, and the place the Aula Magna of the Institute. The ceremony opened, at $10.30 \mathrm{a.m}$., with éloges pronounced by Senator Castelnuovo and the Rector of the University. Then followed a discourse by Prof. G. Sansone, of Florence, who, in his capacity of co-director of the Annali, gave a brief history of the journal and presented the three current volumes to - Prof. Severi. The fourth leading speech was made by Prof. B. Segre, of Bologna, who, as editor of the "Collected Papers" and with the authority of the master's most distinguished pupil, illustrated the author's scientific achievements, particularly in the field covered by the first volume. To these addresses Prof. Severi replied in simple and moving terms.

On the same evening, a reception was given by Signora and Prof. Severi at their home, at which many Italian mathematicians and notabilities, as well as the foreign guests, were present.

The Congress proper opened on the morning of April 26 and continued, with two daily sessions, until April 28. The speakers were drawn from many European countries, including Poland and also the U.S.S.R., of which the delegation of four was led by Prof. P. S. Alexandroff. From the British Isles came Prof. A. S. Besicovitch, Prof. L. J. Mordell, Mr. L. Roth, Prof. J. G. Semple and Prof. J. L. Synge, all of whom made communications. The opening address was given by Prof. W. Sierpinski, of Poland; about twenty papers were read, covering such topics as algebra, the theory of aggregates, number theory, functions of a real or complex variable, algebraic and differential geometry, topology, differential equations, mechanics and electrodynamics. While some of the papers (in Italian, English, French or German) were of the usual congress type, reporting developments in a selected field, most of them represented original work, some of it actually written for the occasion. It is impossible to give further details here, and it must suffice to note that the University of Rome intends to publish the proceedings in a special volume of the Rendiconti of its mathematical seminar, which will include also an account of the ceremony of April 25; this should be available in the near future.

During the three days of the conference the authorities of the University and the City continued their hospitality. On the afternoon of April 27 the Accademia Nazionale dei XL gave a reception in the beautiful cloisters of the Museo delle Terme, which at the same time provided an opportunity of viewing some of the finest extant specimens of Greek and Roman sculpture. Other receptions were held by Profs. E. Bompiani and M. Picone. On the evening of April 28 Signora and Prof. Severi gave a dinner at the Grand Hotel to their foreign guests, who were thus afterwards enabled to express publicly their thanks and to tender their good wishes to the host and hostess.

On April 29 the visitors made their way to Arezzo, Prof. Severi's birthplace, where a civic reception, a presentation by the Accademia Petrarca and other celebrations followed. The next day a whole programme of tours and ceremonies was carried out in the neighbouring country of the Casentino, culminating in an oration by Prof. Severi on Dante, in reply to his election as honorary member of the Dante Society of Bibbiena.

So ended a series of festivities, spiritual and worldly, which none of the participants is ever likely to forget. The kindness and generosity of the organisers, and the smooth working of the programmo in all its details, will leave an indelible imprint; while to the newcomers to the scene an eminent mathematician has been revealed as a great, indeed a paramount, personality. 